\title{
In vitro acaricidal activity of different ectoparasiticide classes against Amblyomma sculptum larvae
}

\author{
Atividade acaricida in vitro de diferentes classes de ectoparasiticidas frente a \\ larvas de Amblyomma sculptum
}

Debora Azevedo Borges ${ }^{1 *}$ (D); Yara Peluso Cid²; Barbara Rauta de Avelarri; Thais Paes Ferreira ${ }^{3}$; Diefrey Ribeiro Campos ${ }^{1}$; Gabriela Carmelinda Martins dos Santos ${ }^{1}$; Melina Cardilo Campos Alves ${ }^{1}$; Fabio Barbour Scott ${ }^{1}$

' Departamento de Parasitologia Animal, Instituto de Veterinária, Universidade Federal Rural do Rio de Janeiro - UFRRJ, Seropédica, RJ, Brasil

${ }^{2}$ Departamento de Ciências Farmacêuticas, Institutos de Ciências Biológicas e da Saúde, Universidade Federal Rural do Rio de Janeiro - UFRRJ, Seropédica, RJ, Brasil

${ }^{3}$ Departamento de Química Analítica, Instituto de Química, Universidade Federal Rural do Rio de Janeiro - UFRRJ, Seropédica, RJ, Brasil

How to cite: Borges DA, Cid YP, Avelar BR, Ferreira TP, Campos DR, Santos GCM, et al. In vitro acaricidal activity of different ectoparasiticide classes against Amblyomma sculptum larvae. Braz J Vet Parasitol 2020; 29(3): e003020. https://doi.org/10.1590/ S1984-29612020052

\begin{abstract}
Zoonoses are major causes of morbidity and mortality worldwide. Among them, Brazilian Spotted Fever (BSF) is an important one that occurs in some regions of South America and can be transmitted by the "star tick" Amblyomma sculptum. Application of acaricides against the larval stage is important as strategy of population control. However, there is still a deficiency of studies on chemical control of $A$. sculptum and the present work aims to evaluate the in vitro acaricidal activity of cypermethrin, flumethrin, deltamethrin, fipronil, coumaphos and chlorpyrifos against A. sculptum larvae. Bioassays were performed using the larval immersion test method. A discriminatory analysis between the antiparasitic classes most used for tick control was carried out, which made it possible to determine the classes with higher potential for controlling $A$. sculptum larvae. Our results showed that $A$. sculptum larvae present highest sensitivity to the synthetic pyrethroid group, followed by the phenylpyrazole, organophosphate and macrocyclic lactone groups. These findings may support studies on improvement of tick control as in animals as in the environment.
\end{abstract}

Keywords: Star tick, tick control, in vitro assay.

\section{Resumo}

As zoonoses são a maior causa de morbidade de mortalidade no mundo. A Febre Maculosa Brasileira (FMB) é uma importante zoonose que ocorre em algumas regiões da América do Sul e pode ser transmitida pelo "carrapato-estrela" Amblyomma sculptum. A aplicação de acaricidas, frente ao estágio larval, é importante como estratégia no controle da população. No entanto, ainda há uma deficiência de estudos para o controle químico de A. sculptum. Devido à necessidade de mais informações sobre o controle de A. sculptum, o presente trabalho tem como objetivo avaliar a atividade acaricida in vitro de cipermetrina, flumetrina, deltametrina, fipronil, coumafós e clorpirifós frente a larvas de A. sculptum. Os bioensaios foram realizados pelo método Teste de Imersão de Larva. Foi realizada uma análise discriminatória entre as classes antiparasitárias mais utilizadas para controle de carrapatos, possibilitando determinar classes com maior potencial para o controle de larvas de A. sculptum. Os resultados deste trabalho mostraram que as larvas de $A$. sculptum apresentam maior sensibilidade ao grupo dos piretroides sintéticos, seguido pelos grupos fenilpirazóis, organofosforados e lactonas macrocíclicas. Esses achados poderiam apoiar estudos visando ao controle do carrapato tanto em animais quanto no meio ambiente.

Palavras-chave: Carrapato-estrela, controle de carrapatos, ensaio in vitro.

Received February 11, 2020. Accepted May 21, 2020.

*Corresponding author: Debora Azevedo Borges. E-mail: deb_vet@hotmail.com 


\section{Introduction}

Ticks are widely distributed in Brazil with 70 species, being the Amblyomma genera (32 spp.) the most representative (Dantas-Torres et al., 2019). They need to feed on the blood of vertebrates (mainly mammals) and are responsible for causing cutaneous lesions, anemia, inoculation of toxins and transmission of pathogens. These occurrences can lead to host death (Prata, 2005; Rodrigues et al., 2015; Moraes-Filho, 2017). Amblyomma sculptum Berlese, during a long time cited as Amblyomma cajennense (Fabricius), also called by "star tick", the most important tick species, given that it has the capacity to parasitize several animal species, including humans. Infected ticks can transmit the bacterium Rickettsia rickettsii, etiological agent of Brazilian Spotted Fever (BSF), an important zoonosis and the most lethal rickettsiosis in the world (Bechah et al., 2008; Labruna et al., 2002; Labruna, 2009).

Amblyomma sculptum is part of a complex of six species (A. cajennense sensu stricto s.s., Amblyomma mixtum Koch, A. sculptum, Amblyomma tonelliae Nava, Beati \& Labruna, Amblyomma interandinum Beati, Nava \& Cáceres and Amblyomma patinoi Labruna, Nava \& Beati), named Amblyomma cajennense complex. Each of the species reported has a distinct geographical distribution. The species A. sculptum is commonly found in Argentina, Bolivia, Paraguay and peri-Amazonian areas of Brazil (in the states of Rio de Janeiro, Espírito Santo, Minas Gerais, São Paulo, Paraná, Pernambuco, Piauí, Mato Grosso, Mato Grosso do Sul and Goiás). Thus, previous occurrences of "star ticks" reported as A. cajennense causing BSF in these regions of Brazil were probably due to A. sculptum (Nava et al., 2014).

Although A. sculptum has low parasitic specificity, especially in the immature phases, capybaras and horses are the preferred hosts for all stages of this species (Labruna et al., 2001). For effective control over BSF, strategic tick control could be useful, in order to reduce the number of ectoparasites both among animals and in the environment. The immature stages of ticks are more sensitive to acaricides than is the adult stage. Therefore, reduction of the immature tick population consequently provides a reduction in the number of adults (Rodrigues et al., 2015). The main classes of acaricides currently used in Brazil, via the topical route, are macrocyclic lactones, phenylpyrazoles, pyrethroids and organophosphates. However, there is still a deficiency of studies on chemical control over A. sculptum.

Given the need for more information about $A$. sculptum control and to enable and ensure the efficacy and safety of the use of active ingredients for controlling ticks, it is first necessary to determine the effective concentrations. Evaluation of in vitro activity and estimation of $\mathrm{LC}_{50}$ and $\mathrm{LC}_{90}$ values are important tools at this stage. Therefore, the aim of the present study was to evaluate the in vitro acaricidal activity of cypermethrin, flumethrin, deltamethrin, fipronil, coumaphos and chlorpyrifos against $A$. sculptum larvae.

\section{Material and methods}

\section{Reagents and chemicals}

Technical-grade reagents were purchased as follows: acetone and Triton-X from Vetec ${ }^{\circledR}$ (Duque de Caxias, BR), $\mathrm{N}$-methylpyrrolidone (NMP) and ethanol from Synth ${ }^{\circledR}$ (Diadema, BR) and xylene from Isofar ${ }^{\circledR}$ (Duque de Caxias, BR). The technical-grade active ingredients cypermethrin (93.1\%), flumethrin (97.4\%) and fipronil (99.2\%) were provided by CEVA ${ }^{\circledast}$ (Paulínia, BR). Technical-grade coumaphos (98.1\%), chlorpyrifos (98.7\%) and ivermectin (98.7\%) were provided by Champion ${ }^{\circledast}$ (Campinas, BR). Butox ${ }^{\circledast}$ MSD (deltamethrin) was purchased from a local market.

\section{Preparation of test solutions}

The emulsifiable concentrates of each technical-grade active ingredient were prepared as described in Table 1. The surfactant Triton- $x$ was added to all the emulsifiable concentrates at $2 \%$. Different solvents (ethanol, $\mathrm{N}$-methylpyrrolidone, xylene and acetone) were used to ensure complete solubilization of the active ingredients. Stock solutions were prepared through dilutions $(1: 100)$ of the emulsifiable concentrates in pure water. Working concentrations $(n=10)$ were prepared using the diluents at the concentration range described in Table 1. The test solutions were prepared in accordance with the recommendations of the FAO Guidelines for Resistance Management and Integrated Parasite Control in Ruminants (FAO, 2004).

\section{In vitro larvicidal assay}

The experiments followed the standards established by the Ethics Committee for Animal Use (CEUA) of the Veterinary Institute, Federal Rural University of Rio de Janeiro (UFRRJ). The larvae of A. sculptum (CEUA/IV no. 7699190418) that were used in the experiment were obtained from colonies maintained in rabbits in the Laboratory for Experimental Chemotherapy in Veterinary Parasitology of UFRRJ. 
Table 1. Preparation of emulsifiable concentrates and test solutions of active ingredients for in vitro larvicidal assays.

\begin{tabular}{|c|c|c|c|c|c|c|}
\hline \multirow{2}{*}{ Class } & \multirow{2}{*}{ Active } & \multicolumn{2}{|c|}{ Emulsifiable concentrate** } & \multirow{2}{*}{$\begin{array}{c}\begin{array}{c}\text { Stock } \\
\text { solution*** }\end{array} \\
\% \mathrm{Al}\end{array}$} & \multirow{2}{*}{$\begin{array}{c}\text { Diluent composition } \\
\star \star \star \star \star\end{array}$} & \multirow{2}{*}{$\begin{array}{c}\text { Concentration range } \\
\left(\mu \mathrm{g} \cdot \mathrm{mL}^{-1}\right)\end{array}$} \\
\hline & & $\% \mathrm{Al}$ & Vehicle & & & \\
\hline$M L$ & Ivermectin & 5 & $\mathrm{EtOH}$ & 0.05 & $1 \% \mathrm{EtOH}$ & $0.1-10.000$ \\
\hline \multirow[t]{2}{*}{ OP } & Coumaphos & 1 & NMP & 0.010 & $1 \% \mathrm{NMP}$ & $1-100$ \\
\hline & Chlorpyrifos & 20 & $50 \%$ acetone $50 \%$ xylene & 0.20 & $\begin{array}{l}0.50 \% \text { acetone } \\
0.50 \% \text { xylene }\end{array}$ & $5-1250$ \\
\hline PYZ & Fipronil & 1 & Acetone & 0.010 & $1 \%$ acetone & $1-60$ \\
\hline \multirow[t]{3}{*}{ SP } & Cypermethrin & 5 & $50 \%$ acetone $50 \%$ xylene & 0.050 & $0.50 \%$ acetone $0.50 \%$ & $5-50$ \\
\hline & Flumethrin & 0.10 & & 0.001 & & $0.0012-0.62$ \\
\hline & Deltamethrin* & 2.5 & & 0.025 & $0.02 \%$ Triton & $0.50-20$ \\
\hline
\end{tabular}

ML: Macrocyclic Lactones; OP: Organophosphates; PYZ: Phenylpyrazole; SP: Synthetic Pyrethroids; NMP: N-methylpyrrolidone; Al: Active Ingredient; EtOH: ethanol; NMP: N-methyl-pyrrolidone. *Commercial product Butox ${ }^{\circledR} ;{ }^{\star *}$ Triton-x added at $2 \%$; $* \star * P r e p a r e d$ in pure water; $\star \star \star \star T r i t o n-X$ $0.02 \%$ in pure water.

The colony of $A$. sculptum was created from fed females collected from horses in the UFRRJ herd that did not receive any carrapaticidal treatment in the last 6 months. For the in vitro assay, 12th generation larvae were used.

The bioassays were performed using the larval immersion test (LIT) method (Shaw, 1966), as adapted by Leite (1988) and Chagas et al. (2002). For each concentration, approximately 100 non-fed 35-day-old larvae of A. sculptum were deposited on a $2 \mathrm{~cm} \times 2 \mathrm{~cm}$ filter paper sandwich, which was impregnated with $0.5 \mathrm{~mL}$ of the test solution. The filter paper sandwich was wrapped in a filter paper envelope $(6 \mathrm{~cm} \times 6 \mathrm{~cm})$ that was then properly sealed with binder clips. The envelopes were kept in a climatized chamber at $27 \pm 1^{\circ} \mathrm{C}$ and relative humidity of $80 \pm 10 \%$. The mortality assessment was performed after 24 hours for organophosphates, phenylpyrazole and synthetic pyrethroids and after 48 hours for macrocyclic lactones (FAO, 2004). The evaluation criterion used was motility, i.e. any larva that presented minimal movement was considered alive. The mean number of live larvae per concentration was evaluated with the aid of a stereomicroscope. The tests were performed in duplicate for each concentration. Mortality was calculated in accordance with the following formula proposed by Abbott (1925): Mortality $(\%)=$ dead larvae $\times 100 /$ total larvae.

\section{Statistical analysis}

The Probit analysis method was used to assess $L C_{50}$ and $L C_{90}$ lethal concentration values together with their $95 \%$ confidence interval $(95 \% \mathrm{Cl})\left(\mu \mathrm{g} \cdot \mathrm{mL}^{-1}\right)$ and the slope $\pm \mathrm{SE}$ of the concentration curve, with the $\chi^{2}$ test to determine the accuracy of data fitting. The goodness-of-fit test showed that the values did not present any significant heterogeneity at the level of $p \geq 0.05$. The Probit analysis estimates were calculated using the IBM SPSS statistical software, version 23.

\section{Results}

\section{Mortality}

The bioassay results showed that all the active ingredients tested exhibited acaricidal activity against $A$. sculptum larvae (Table 2). The best efficacy results were found for the synthetic pyrethroid group, which achieved $100 \%$ efficacy at the concentrations of $0.625 \mu \mathrm{g} \cdot \mathrm{mL}^{-1}, 5 \mu \mathrm{g} \cdot \mathrm{mL}^{-1}$ and $20 \mu \mathrm{g} \cdot \mathrm{mL}^{-1}$, for flumethrin, deltamethrin and cypermethrin respectively. Organophosphates and phenylpyrazole also presented good results with $100 \%$ efficacy at $500 \mu \mathrm{g} \cdot \mathrm{mL}^{-1}$, $75 \mu \mathrm{g} \cdot \mathrm{mL}^{-1}$ and $60 \mu \mathrm{g} \cdot \mathrm{mL}^{-1}$, for chlorpyrifos, coumaphos and fipronil respectively. Ivermectin achieved $100 \%$ efficacy at the highest concentration $\left(5500 \mu \mathrm{g} \cdot \mathrm{mL}^{-1}\right)$. 
Table 2. In vitro activity through larvae immersion test (\% mortality) against larvae of Amblyomma sculptum.

\begin{tabular}{|c|c|c|c|c|c|c|c|c|c|c|c|c|c|}
\hline \multicolumn{2}{|c|}{ Chlorpyrifos } & \multicolumn{2}{|c|}{ Coumaphos } & \multicolumn{2}{|c|}{ Cypermethrin } & \multicolumn{2}{|c|}{ Flumethrin } & \multicolumn{2}{|c|}{ Deltamethrin } & \multicolumn{2}{|c|}{ Fipronil } & \multicolumn{2}{|c|}{ Ivermectin } \\
\hline Conc. & $\%$ & Conc. & $\%$ & Conc. & $\%$ & Conc. & $\%$ & Conc. & $\%$ & Conc. & $\%$ & Conc. & $\%$ \\
\hline 5 & 0 & 1 & 0 & 5 & 0 & 0.001 & 0 & 0.5 & 3 & 1 & 0 & 0.1 & 0 \\
\hline 10 & 0 & 2.5 & 0 & 6 & 5 & 0.002 & 0 & 1 & 13 & 2.5 & 29 & 0.5 & 0 \\
\hline 50 & 70 & 5 & 5 & 7 & 36 & 0.005 & 0 & 2 & 75 & 5 & 31 & 1.0 & 0 \\
\hline 100 & 80 & 7.5 & 10 & 8 & 92 & 0.010 & 0 & 3 & 94 & 7.5 & 41 & 5.5 & 0 \\
\hline 250 & 95 & 10 & 67 & 9 & 97 & 0.020 & 30 & 4 & 99 & 10 & 89 & 10 & 0 \\
\hline 350 & 97 & 20 & 88 & 10 & 98 & 0.039 & 26 & 5 & 100 & 20 & 99 & 55 & 10 \\
\hline 500 & 100 & 35 & 95 & 20 & 100 & 0.078 & 59 & 8 & 97 & 30 & 98 & 100 & 35 \\
\hline 750 & 100 & 50 & 91 & 30 & 100 & 0.156 & 85 & 10 & 98 & 40 & 99 & 550 & 84 \\
\hline 1000 & 100 & 75 & 100 & 40 & 100 & 0.313 & 93 & 15 & 100 & 50 & 98 & 1000 & 93 \\
\hline 1250 & 99 & 100 & 99 & 50 & 100 & 0.625 & 100 & 20 & 100 & 60 & 100 & 5500 & 100 \\
\hline
\end{tabular}

Conc.: Concentration of active ingredients expressed in $\mu \mathrm{g} . \mathrm{mL}^{-1} ; \%$ : Mortality (\%) among Amblyomma sculptum larvae after 24 hours for chlorpyrifos, coumaphos, cypermethrin, flumethrin, deltamethrin and fipronil and after 48 hours for ivermectin.

\section{$L C_{50}$ and $L C_{90}$ estimates}

The $L C_{50}$ and $L C_{90}$ values for the active ingredients evaluated, against $A$. sculptum larvae, are described in Figure 1. The $\mathrm{LC}_{50}$ ranged from $0.06 \mu \mathrm{g} \cdot \mathrm{mL}^{-1}$ to $187.275 \mu \mathrm{g} \cdot \mathrm{mL}^{-1}$, while the $\mathrm{LC}_{90}$ ranged from $0.216 \mu \mathrm{g} \cdot \mathrm{mL}^{-1}$ to $711.084 \mu \mathrm{g} \cdot \mathrm{mL}^{-1}$. The linear regression coefficient ( $r$ ) was higher than 0.85 and the $p$-value of the goodness-of-fit test was higher than 0.05 for all the active ingredients evaluated. This demonstrated through the Probit analysis that the data fitting was accurate, without any significant heterogeneity (Table 3).

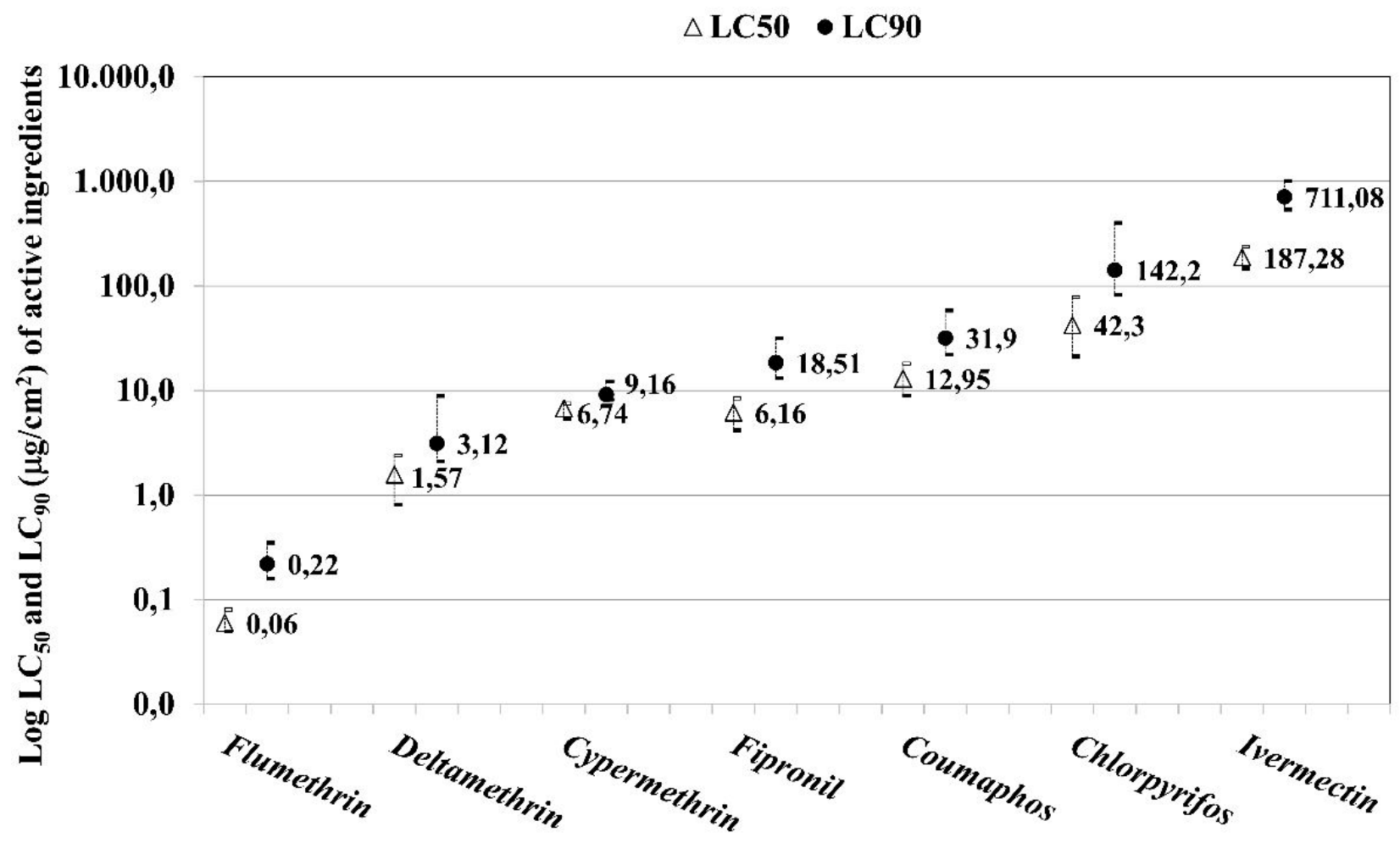

Figure 1. $\mathrm{LC}_{50}$ and $\mathrm{LC}_{90}$ values for active ingredients evaluated against Amblyomma sculptum larvae. 
Table 3. Probit analyses on mortality data obtained from bioassays against larvae of Amblyomma sculptum.

\begin{tabular}{|c|c|c|c|c|c|}
\hline & $\begin{array}{l}\mathrm{LC}_{50}\left(\mu \mathrm{g} \cdot \mathrm{mL}^{-1}\right) \\
(95 \% \mathrm{Cl})\end{array}$ & $\begin{array}{c}\mathrm{LC}_{90}\left(\mu \mathrm{gg} \cdot \mathrm{mL}^{-1}\right) \\
(95 \% \mathrm{Cl})\end{array}$ & Slope (SE) & $r$ & $\chi^{2}$ \\
\hline Flumethrin & $\begin{array}{c}0.060 \\
(0.039-0.075)\end{array}$ & $\begin{array}{c}0.231 \\
(0.164-0.395)\end{array}$ & $1.89(0.107)$ & 0.962 & 0.055 \\
\hline Deltamethrin & $\begin{array}{c}1.568 \\
(0.812-2.395)\end{array}$ & $\begin{array}{c}3.116 \\
(2.085-8.849)\end{array}$ & $4.296(0.213)$ & 0.882 & 0.085 \\
\hline Cypermethrin & $\begin{array}{c}7.080 \\
(3.367-8.097)\end{array}$ & $\begin{array}{c}8.243 \\
(7.255-19.285)\end{array}$ & $19.402(1.504)$ & 0.929 & 0.094 \\
\hline Coumaphos & $\begin{array}{c}12.951 \\
(8.988-18.134)\end{array}$ & $\begin{array}{c}31.875 \\
(22.289-58.236)\end{array}$ & $3.276(0.171)$ & 0.869 & 0.071 \\
\hline Chlorpyrifos & $\begin{array}{c}45.251 \\
(21.210-78.135)\end{array}$ & $\begin{array}{c}142.222 \\
(81.99-401.407)\end{array}$ & $2.577(0.159)$ & 0.980 & 0.092 \\
\hline Ivermectin & $\begin{array}{c}187.275 \\
(147.277-236.652)\end{array}$ & $\begin{array}{c}711.084 \\
(536.487-1013.40)\end{array}$ & $2.212(0.193)$ & 0.987 & 0.977 \\
\hline Fipronil & $\begin{array}{c}6.157 \\
(4.174-8.378)\end{array}$ & $\begin{array}{c}18.514 \\
(13.170-31.599)\end{array}$ & $2.68(0.12)$ & 0.856 & 0.083 \\
\hline
\end{tabular}

Probit analyses were performed for all data using the IBM SPSS statistical software, version 23. Data are given as $50 \%\left(\mathrm{LC}_{50}\right)$ and $90 \%\left(\mathrm{LC}_{90}\right)$ lethal concentration values together with their $95 \%$ confidence interval $(95 \% \mathrm{CI})\left(\mu \mathrm{g} \cdot \mathrm{mL}^{-1}\right)$; the slope $\pm \mathrm{SE}$ of the concentration curve; and the $\chi^{2}$ test as the accuracy of data fitting to the Probit analysis (goodness-of-fit test: values did not show any significant heterogeneity at the level of $p \geq 0.05$ ).

\section{Discussion}

The scarcity of studies for the control of $A$. sculptum is perhaps one of the reasons that in the last 30 years few products have been launched with instructions for use in horses, with the use of off-label products in these animals being common. Labruna et al. (2004) reported that only a few pyrethroid formulations would be available for the control of $A$. cajennense in horses.

Our results showed that $A$. sculptum larvae presented highest sensitivity to the synthetic pyrethroid group, followed by the phenylpyrazole, organophosphate and macrocyclic lactone groups. These active groups present different modes of action, as follows: via the Gaba chloride channel for ivermectin and fipronil (Papich, 2012; Barros \& Di Stasi, 2012); via the kinetics of sodium channels for pyrethroids (Adams, 2003); and via irreversible inhibitors of acetylcholinesterase for organophosphates (Barros \& Di Stasi, 2012). These groups are widely used for tick control (Taylor, 2001), but there is a lack of knowledge about their activity against $A$. sculptum.

Bittencourt et al. (1989) evaluated in vitro non-fed larvae of $A$. cajennense sensu lato against different pyrethroids (deltamethrin, alfamethrin, flumethrin and fenvalerate) and, as in the present study, the authors also found that flumethrin obtained better results $\left(\mathrm{LC}_{50}=0.85 \mu \mathrm{g} \cdot \mathrm{mL}^{-1}\right.$ and $\left.\mathrm{LC}_{90}=2.7 \mu \mathrm{g} \cdot \mathrm{mL}^{-1}\right)$. The other pyrethroids showed larvicidal activity in higher concentrations: deltamethrin $\left(\mathrm{LC}_{50}=2.2 \mu \mathrm{g} \cdot \mathrm{mL}^{-1}\right.$ and $\left.\mathrm{LC}_{90}=6.2 \mu \mathrm{g} \cdot \mathrm{mL}^{-1}\right)$, alfamethrin $\left(\mathrm{LC}_{50}=2.4 \mu \mathrm{g} \cdot \mathrm{mL}^{-1}\right.$ and $\left.\mathrm{LC}_{90}=23 \mu \mathrm{g} \cdot \mathrm{mL}^{-1}\right)$ and fenvalerate $\left(\mathrm{LC}_{50}=7.5 \mu \mathrm{g} \cdot \mathrm{mL}^{-1}\right.$ and $\left.\mathrm{LC}_{90}=80 \mu \mathrm{g} \cdot \mathrm{mL}^{-1}\right)$

Among the pyrethroids evaluated in the present study, the larvicidal activity of flumethrin was most pronounced $\left(\mathrm{LC}_{50}=0.06 \mu \mathrm{g} \cdot \mathrm{mL}^{-1}\right.$ and $\left.\mathrm{LC}_{90}=0.23 \mu \mathrm{g} \cdot \mathrm{mL}^{-1}\right)$ lower than that observed by Bittencourt et al. (1989), with relative potency that was up to 13-fold and 35-fold higher than those of deltamethrin $\left(\mathrm{LC}_{50}=1.56 \mu \mathrm{g} \cdot \mathrm{mL}^{-1}\right.$ and $\left.\mathrm{LC}_{90}=3.11 \mu \mathrm{g} \mathrm{mL} \mathrm{L}^{-1}\right)$ and cypermethrin $\left(\mathrm{LC}_{50}=7.08 \mu \mathrm{g} \cdot \mathrm{mL}^{-1}\right.$ and $\left.\mathrm{LC}_{90}=8.24 \mu \mathrm{g} \cdot \mathrm{mL}^{-1}\right)$, respectively.

Ticks used in both studies (ours and Bittencourt et al., 1989) obtained their colonies from specimens collected from horses in the UFRRJ herd. After 30 years, the $\mathrm{LC}_{50}$ levels for flumethrin and deltamethrin do not increase, indicating that the susceptibility of this population over time has not undergone significant changes in sensitivity. A possible explanation for this fact in Brazil would be the use of fipronil off-label, since its commercial presentation is intended for use in cattle.

In an in vitro study conducted with non-fed larvae of $A$. cajennense in the state of Goiás, Brazil, Freitas et al. (2011) evaluated the susceptibility of a population to different ectoparasiticides: deltamethrin $\left(\mathrm{LC}_{50}=0.03 \mu \mathrm{g} \cdot \mathrm{mL}^{-1}\right.$ and $\left.\mathrm{LC}_{90}=0.2 \mu \mathrm{g} \cdot \mathrm{mL}^{-1}\right)$, permethrin $\left(\mathrm{LC}_{50}=0.06 \mu \mathrm{g} \cdot \mathrm{mL}^{-1}\right.$ and LC $\left.90=1.15 \mu \mathrm{g} \cdot \mathrm{mL}^{-1}\right)$, cypermethrin + piperonyl butoxide (PBO) $\left(\mathrm{LC}_{50}=0.017 \mu \mathrm{g} \cdot \mathrm{mL}^{-1}\right.$ and $\left.\mathrm{LC}_{90}=0.81 \mu \mathrm{g} \cdot \mathrm{mL}^{-1}\right)$ and amitraz $\left(\mathrm{LC}_{50}=0.003 \mu \mathrm{g} \cdot \mathrm{mL}^{-1}\right.$ and $\left.\mathrm{LC}_{90}=3.6 \mu \mathrm{g} \cdot \mathrm{mL}^{-1}\right)$. The $\mathrm{LC}_{50}$ of deltamethrin and cypermethrin obtained in the present study were higher than those observed by 
Freitas et al. (2011). This fact may be related to a lower susceptibility of this population, however for cypermethrin it is important to note that the association with PBO may have caused a synergistic effect, promoting greater efficacy (Taylor, 2001).

Alonso-Díaz et al. (2013), carried out several in vitro studies in Mexico to determine the levels of susceptibility of populations of $A$. cajennense to different synthetic acaricides, observing high frequencies of resistance to organophosphates and amitraz. The authors highlight the need for more in vitro studies to be carried out to monitor susceptibility levels.

Despite the relevance that this parasite has for horses and human's health, there is still a lack of in vitro and in vivo studies to evaluate synthetic acaricides that can be used in the control of horse ticks. The determination of the acaricidal action of the active ingredients used in the present study against $A$. sculptum is relevant, as it indicates that all of them presented efficacy levels, however it is emphasized that the results found do not allow us to state that they can be used to control this tick.

The study was evaluated with non-fed larvae and as stated by Bittencourt et al. (1989), this stage is the one that presents the greatest susceptibility to pyrethroids. Other studies should be conducted with the other stages (not fed and fed) in order to be able to affirm that an active ingredient has high potential to be used in the control of $A$. sculptum. The bioassays with A. sculptum larvae can serve as initial tests for the selection of promising active ingredients, as well as for the monitoring of resistant populations.

\section{Conclusion}

The synthetic pyrethroids deltamethrin, cypermethrin and flumethrin and the phenylpyrazole fipronil demonstrated high larvicidal efficacy in in vitro assays against the larvae of Amblyomma sculptum.

\section{Acknowledgements}

This study was supported by the Support Foundation for Technological Research (Fundação de Apoio à Pesquisa Tecnológica, FAPUR) of the Federal Rural University of Rio de Janeiro, Coordination Office for Improvement of Higher-Education Personnel (Coordenação de Aperfeiçoamento Pessoal de Nível Superior, CAPES) and the National Council for Scientific and Technological Development (Conselho Nacional de Desenvolvimento Científico e Tecnológico, CNPq).

\section{References}

Abbott WS. A method of computing the effectiveness of an insecticide. J Econ Entomol 1925; 18(2): 267-269. http://dx.doi. org/10.1093/jee/18.2.265a.

Adams HR. Farmacologia e terapêutica em veterinária. Rio de Janeiro: Guanabara Koogan; 2003.

Alonso-Díaz MA, Férnandez-Salas A, Martínez-Ibánez F, Osorio-Miranda J. Amblyomma cajennense (Acari: Ixodidae) tick populations susceptible or resistant to acaricides in the Mexican Tropics. Vet Parasitol 2013; 197(1-2): 326-331. http://dx.doi.org/10.1016/j. vetpar.2013.06.004. PMid:23827041.

Barros CM, Di Stasi LC. Farmacologia veterinária. São Paulo: Manole; 2012.

Bechah Y, Capo C, Mege JL, Raoult D. Raoult. D Rickettsial diseases: from Rickettsia-arthropod relationships to pathophysiology and animal models. Future Microbiol 2008; 3(2): 223-236. http://dx.doi.org/10.2217/17460913.3.2.223. PMid:18366341.

Bittencourt VREP, Massard CL, Grisi L. Atividade in vitro de alguns piretróides sintéticos no carrapato Amblyomma cajennense (Fabricius, 1787). Pesq Agropec Bras 1989; 24(10): 1193-1199.

Chagas ACS, Passos WM, Prates HT, Leite RC, Furlong J, Fortes ICP. Efeito acaricida de óleos essenciais e concentrados emulsionáveis de Eucalyptus spp em Boophilus microp/us. Braz J Vet Res Anim Sci 2002; 39(5): 247-253. http://dx.doi.org/10.1590/ S1413-95962002000500006.

Dantas-Torres F, Martins TF, Muñoz-Leal S, Onofrio VC, Barros-Battesti DM. Ticks (Ixodida: Argasidae, Ixodidae) of Brazil: Update species checklist and taxonomic keys. Ticks Tick Borne Dis 2019; 10(6): 101252. http://dx.doi.org/10.1016/j.ttbdis.2019.06.012. PMid:31255534.

Food and Agriculture Organization - FAO. Resistance Management and Integrated Parasite Control in Ruminants - Guidelines. Module 1 - Ticks: Acaricide Resistance: Diagnosis, Management and Prevention. Rome: FAO; 2004. p. 25-77. 
Freitas EPS, Zapata MTAG, Fernandes FF. Monitoring of resistance or susceptibility of adults anda larvae of Amblyomma cajennense (Acari: Ixodidae) to synthetic acaricides in Goiás, Brazil. Exp Appl Acarol 2011; 53(2): 189-202. http://dx.doi.org/10.1007/s10493010-9389-1. PMid:20976616.

Labruna MB, Kerber CE, Ferreira F, Faccini JL, De Waal DT, Gennari SM. Risk factors to tick infestations and their occurrence on horses in the state of São Paulo, Brazil. Vet Parasitol 2001; 97(1): 1-14. http://dx.doi.org/10.1016/S0304-4017(01)00387-9. PMid:11337122.

Labruna MB, Paula CD, Lima TF, Sana DA. Ticks (Acari: Ixodidae) on wild animals from the Porto-Primavera hydroelectric power station area, Brazil. Mem Inst Oswaldo Cruz 2002; 97(8): 1133-1136. http://dx.doi.org/10.1590/S0074-02762002000800012. PMid:12563479.

Labruna MB, Leite RC, Gobesso AAO, Gennari SM, Kasai N. Controle estratégico do carrapato Amblyomma cajennense em eqüinos. Cienc Rural 2004; 34(1): 195-200. http://dx.doi.org/10.1590/S0103-84782004000100030.

Labruna MB. Ecology of Rickettsia in South America. Ann N Y Acad Sci 2009; 1166(1): 156-166. http://dx.doi.org/10.1111/j.17496632.2009.04516.x. PMid:19538276.

Leite RC. Boophilus microplus (Canestrini, 1887): susceptibilidade, uso atual e restropectivo de carrapaticidas em propriedades das regiões fisiogeograficas da baixada do Grande-Rio e do Rio de Janeiro, uma abordagem epidemiológica [tese]. Seropédica: Universidade Federal Rural do Rio de Janeiro; 1988

Moraes-Filho J. Febre maculosa brasileira. Rev mv\&z 2017; 15(1): 38-45. https://doi.org/10.36440/recmvz.v15i1.36765

Nava S, Beati L, Labruna MB, Cáceres AG, Mangold AJ, Guglielmone AA. Reassessment of the taxonomic status of Amblyomma cajennense (Fabricius, 1787) with the description of three new species, Amblyomma tonelliae n. p., Amblyomma interandinum n. sp. and Amblyomma patinoi n. sp., and reinstatement of Amblyomma mixtum Koch, 1844, and Amblyomma sculptum Berlese, 1888 (Ixodida: ixodidae). Ticks Tick Borne Dis 2014; 5(3): 252-276. http://dx.doi.org/10.1016/j.ttbdis.2013.11.004. PMid:24556273.

Papich MG. Manual Saunders: Terapia veterinária - pequenos e grandes animais. 3rd ed. Rio de Janeiro: Elsevier; 2012.

Prata MCA. Carrapato estrela: problemas e soluções para animais e humanos. In: Furlong J, editor. Carrapato: problemas e soluções. Juiz de Fora: Embrapa Gado de Leite; 2005. p. 51-65.

Rodrigues VS, Pina FTB, Barros JC, Garcia MV, Andreotti R. Carrapato-estrela (Amblyomma sculptum): Ecologia, Biologia, Controle e Importância. Campo Grande: Embrapa Gado de Corte; 2015. (Comunicado Técnico; 132).

Shaw RD. Culture of an organophosphorus-resistant strain of Boophilus microplus (Can.) and an assessment of its resistance spectrum. Bull Entomol Res 1966; 56(3): 389-405. http://dx.doi.org/10.1017/S0007485300056480. PMid:5945563.

Taylor MA. Recent developments in ectoparasiticides. Vet J 2001; 161(3): 253-268. http://dx.doi.org/10.1053/tvjl.2000.0549. PMid:11352483. 